\title{
Production optimization in well-6 of Habiganj gas field, Bangladesh: a prospective application of Nodal analysis approach
}

\author{
Md. Shaheen Shah ${ }^{1,2} \cdot$ Md Hafijur Rahaman Khan $^{3,4,5}$ (D) Ananna Rahman ${ }^{3,4,5} \cdot$ Stephen Butt $^{1}$
}

Received: 16 February 2020 / Accepted: 6 May 2020 / Published online: 26 May 2020

(c) The Author(s) 2020

\begin{abstract}
The overall performance of gas reservoirs and the optimization of production, as well as its sensitivity analysis, are affected by several factors such as reservoir pressure, well configuration and surface facilities. The Habiganj well no. 06 (HBJ-06) is one of the significant gas-producing vertical wells of the Habiganj gas field, currently producing 14.963 MMscfd of natural gas from the upper gas sand. The widely used Nodal analysis is an optimization technique to improve the performance and was applied for the HBJ-06 to increase its production rate by optimizing manners. By this analysis, each component starting from the reservoir to the outlet pressure of the separator was identified as a resistance in the system by evaluating their inflow performance relationship and vertical lift performance. The F.A.S.T. VirtuWell ${ }^{\mathrm{TM}}$ software package was used to perform this analysis, where the declinations of wellhead pressures were suggested as 1300, 1200, 1100 and 1000 psi(a) without any modification of the tubing diameter and skin factor. Hence, the respective optimized rates of the daily gas production were increased to $38.481,40.993,43.153$ and $46.016 \mathrm{MMscfd}$. At the same time, the optimized condensate gas ratio was calculated as $0.07,0.06,0.06$ and 0.05 , associated with the optimized condensate water ratio of $0.11,0.10,0.09$ and 0.08 , respectively.
\end{abstract}

Keywords Nodal analysis · Gas production optimization · F.A.S.T VirtuWell ${ }^{\mathrm{TM}} \cdot$ IPR $\cdot$ VLP $\cdot$ Habiganj gas field

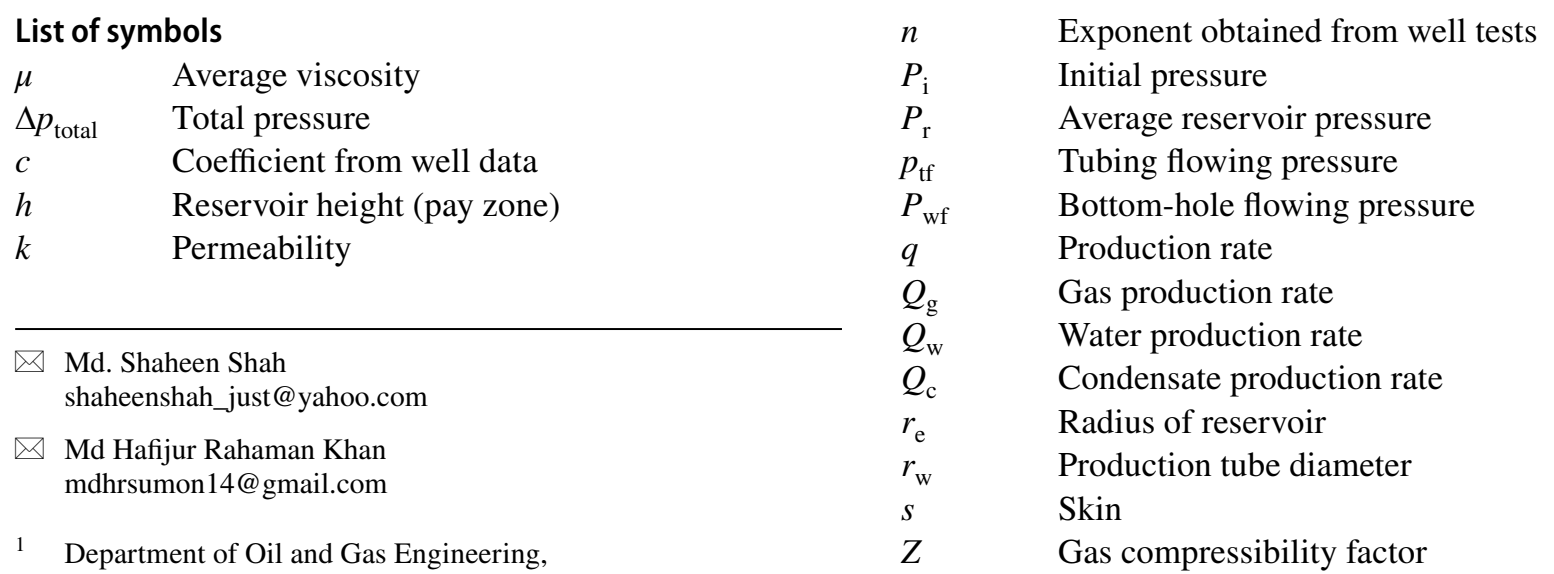

Memorial University of Newfoundland, St. John's, Newfoundland A1C 5S7, Canada

2 Department of Petroleum and Mining Engineering, Jashore University of Science and Technology, Jashore 7408, Bangladesh

\section{Abbreviations}

AOF Absolute open flow

BGFCL Bangladesh Gas Field Company Limited

3 Key Laboratory of Ocean and Marginal Sea Geology, South China Sea Institute of Oceanology, Chinese Academy of Sciences, Guangzhou 510301, China

Bscf

CGR Billion standard cubic feet

4 Innovation Academy of South China Sea Ecology and Environmental Engineering, Chinese Academy of Sciences, Guangzhou 510301, China

5 University of Chinese Academy of Sciences, Beijing 100049, China

Condensate water ratio

DCA Decline curve analysis

EOT End of tubing

GIIP Gas initially in place/gas initial in place

GWC Gas water contact

HCU Hydrocarbon unit of Bangladesh 


$\begin{array}{ll}\text { HGF } & \text { Habiganj gas field } \\ \text { ID } & \text { Inner diameter } \\ \text { IKM } & \text { Intercomp-Kanata Management Limited } \\ \text { IPR } & \text { Inflow performance relationship } \\ \text { km } & \text { Kilometer } \\ \text { LGS } & \text { Lower gas sand } \\ \text { mD } & \text { Millidarcy } \\ \text { MD } & \text { Measured depth } \\ \text { MMscfd } & \text { Million standard cubic feet per day } \\ \text { MPP } & \text { Midpoint of perforation } \\ \text { NPD } & \text { The Norwegian Petroleum Directorate } \\ \text { NPI } & \text { Normalized pressure integral } \\ \text { OD } & \text { Outer diameter } \\ \text { PBTD } & \text { Plug bottom total depth } \\ \text { PDA } & \text { Production data analysis } \\ \text { psi(a) } & \text { Pound per square inch (absolute) } \\ \text { PTA } & \text { Pressure transient analysis } \\ \text { RTA } & \text { Rate transient analysis } \\ \text { Tcf } & \text { Trillion cubic feet } \\ \text { TMD } & \text { Measured tubing depth } \\ \text { TPC } & \text { Tubing performance curves } \\ \text { TVD } & \text { The vertical distance } \\ \text { UGS } & \text { Upper gas sand } \\ \text { VLP } & \text { Vertical lift performance } \\ \text { WGR } & \text { Water gas ratio } \\ & \end{array}$

\section{Introduction}

Energy is an essential prerequisite in industrialization for accomplishing or promising innovative change, economic development, automation and move through the industrialized part all over the world. Generally, natural gas, oil and coal are to be considered as the principal energy sources on the planet, where approximately $35 \%$ of the world's essential energy utilization originates from natural gas (Hussain 1987; Saidur et al. 2010; Hasanuzzaman et al. 2011; Ahmed et al. 2013; Nasir et al. 2013).

In the natural gas or petroleum industry, one of the primary objectives is to maximize and/or draw out the gas/ oil production within the specific and budgetary points of confinement existent (Jaf 2015; Vieira 2015). Therefore, the term "production optimization" denotes the determination and implementation of optimum values of parameters in the production system to maximize hydrocarbon production rate (or discounted revenue) or to minimize the operating cost under various technical and economic constraints (Boyun et al. 2007). In the different industry, production can be optimized by the different approach; however, Nodal (or NODAL) analysis is a method for setting up a well for the generation of oil and/or gas from the reservoir to accomplish the best conceivable proficiency, which was first used by Beggs (2003) in the book of "Production Optimization
Using NODAL Analysis" (Mohaghegh 2011; Sylvester et al. 2015). So, it is defined as a systemic approach to the optimization of oil and gas wells, which is used to evaluate a complete production system thoroughly. Although the entire production system is analyzed as a total unit, individual components are also evaluated individually using this method (Boyun et al. 2007). Every component of a well in a production system can be optimized to achieve the objective flow rate with most economically (Brown and Lea 1985). In the term of Nodal analysis, various computer-based software is used to find out the optimum condition of the production (Khor et al. 2015). The F.A.S.T. VirtuWell ${ }^{\mathrm{TM}}$ is a software package that is used to model, analyze and optimize flow in the wellbores. It allows performing the single and multiphase flow calculations for different wellbore geometries such as vertical, slant, horizontal or complex configurations.

The optimization is specifically dependent on some functions, which might be a single, two or more variables (multivariate optimization), and a well is said to be optimized when it is producing at ideal conditions with the least problems (Beggs 1991; Bath 1998). Thus, the pith of drilling and finishing a production well is to lift oil or gas from its original location in the reservoir (formation) to the stock tank or sale lines. Generally, the engineer utilizes Nodal investigation to locate the best size of tubing, the best operating pressure for the production separator, etc. (decision variables). Any optimization is restricted to differing the choice variables on an experimentation premise to locate a reasonable blend of the variables (Ravindran and Horne 1993; Wang et al. 2002; Wang 2003; Roh et al. 2006). Production optimization can be done in different Nodal applying systems such as changing wellhead pressure, changing skin factor or changing the tubing size of the oil and gas wells (Greene 1983; Brown and Lea 1985). In the early 2000s Haq et al. (2003) PIPESIM software utilized as a part of the production optimization of the Fenchuganj gas field in Bangladesh, it has been shown that changing separator pressure and surface wellhead choke, which improved gas production rate considerably. Moreover, Haq et al. (2005) also observed by using PIPESIM that changing separator pressure and surface wellhead choke, which optimized gas production rate radically in the Fenchuganj gas field (Haq et al. 2005). Contrariwise, General Allocation Package (GAP) analysis has been applied in conducting the system analysis by changing tubing ID and separator pressure resulting in optimized gas production at Saldanadi gas field and Kailastila gas field. (Salekin 2011; Ahmed 2012). Rahman and Akter (2014) investigated that tubing ID and perforation depth got new optimized well deliverability by changing the value of skin in the Habiganj gas field. Shah and Hossain (2015) evaluated the natural gas production optimization of the Kailashtila gas field by using F.A.S.T. Virtu Well ${ }^{\mathrm{TM}}$ through decreasing wellhead pressure as the Nodal analysis approach. Additionally, Faruque et al. 
(2018) investigated on the gas production optimization by decreasing skin and changing tubing size without changing the wellhead pressure by using F.A.S.T. Virtu Well ${ }^{\mathrm{TM}}$.

The case study of gas production optimization between two different nodes in the same well of a typical gas field using nodal analysis resolves that the oil/gas can be produced more by reducing wellhead pressure than decreasing skin and increasing tubing size neglecting some minor limitations (Shah and Hossain 2015; Faruque et al. 2018). In addition, some other studies completed in Bangladesh (Haq et al. 2003, 2005; Salekin 2011; Ahmed 2012) also showed favorable results by changing wellhead pressure. Nevertheless, damage or stimulation around the wellbore in the formation of oil/gas is known as the skin factor. Positive skin can be caused by things like mud and cement infiltration, wax/asphaltene, water vapor evaporation, etc. On the contrary, processes such as acidizing, solvent injection and hydraulic fracturing can cause negative skin (Dake 1978; Guo 2019). So, the skin factor in the current well has not been changed. Furthermore, when the size of the tubing becomes larger than the critical tubing size, then it can reduce the production rate as a result of increasing the size of the tubing if the tubing size of the gas well cannot meet the requirement of carrying liquid that may cause a decrease in production rate (Wan 2011). Therefore, the size of the tubing is considered as the constant of the currently used well. This study considers the reduction in well pressure upon the Habiganj gas field.

In Bangladesh, 20 gas fields out of 26 are producing approximately 2730 MMscfd through 101 wells against a demand of 3200 MMscfd cause a deficiency of 500 MMscfd during 2016 (BGFCL 2016). Therefore, to supply the gas as per the demand, either more wells have to be drilled or production should be increased by applying appropriate enhancement techniques or the Nodal analysis approach. The point of this study has attempted a prospective application of Nodal analysis by F.A.S.T. VirtuWell ${ }^{\mathrm{TM}}$ software to optimize gas production of HBJ-06 in Habiganj gas field.

\section{Habiganj gas field}

Habiganj gas field (HGF) lies in Madhabpur Upazila under the Habiganj district, northwestern Bangladesh, which is about $100 \mathrm{~km}$ to northeastern from the capital city of Dhaka and located at $24.3750^{\circ} \mathrm{N}$ and $91.4167^{\circ} \mathrm{E}$ (Fig. 1). It is bounded by Sunamganj district to the north, Tripura of India and Maulvibazar district to the east, Sylhet district to the northeast, Brahmanbaria and Kishoreganj districts to the west covering the total area of $2636.58 \mathrm{~km}^{2}$. Titas gas

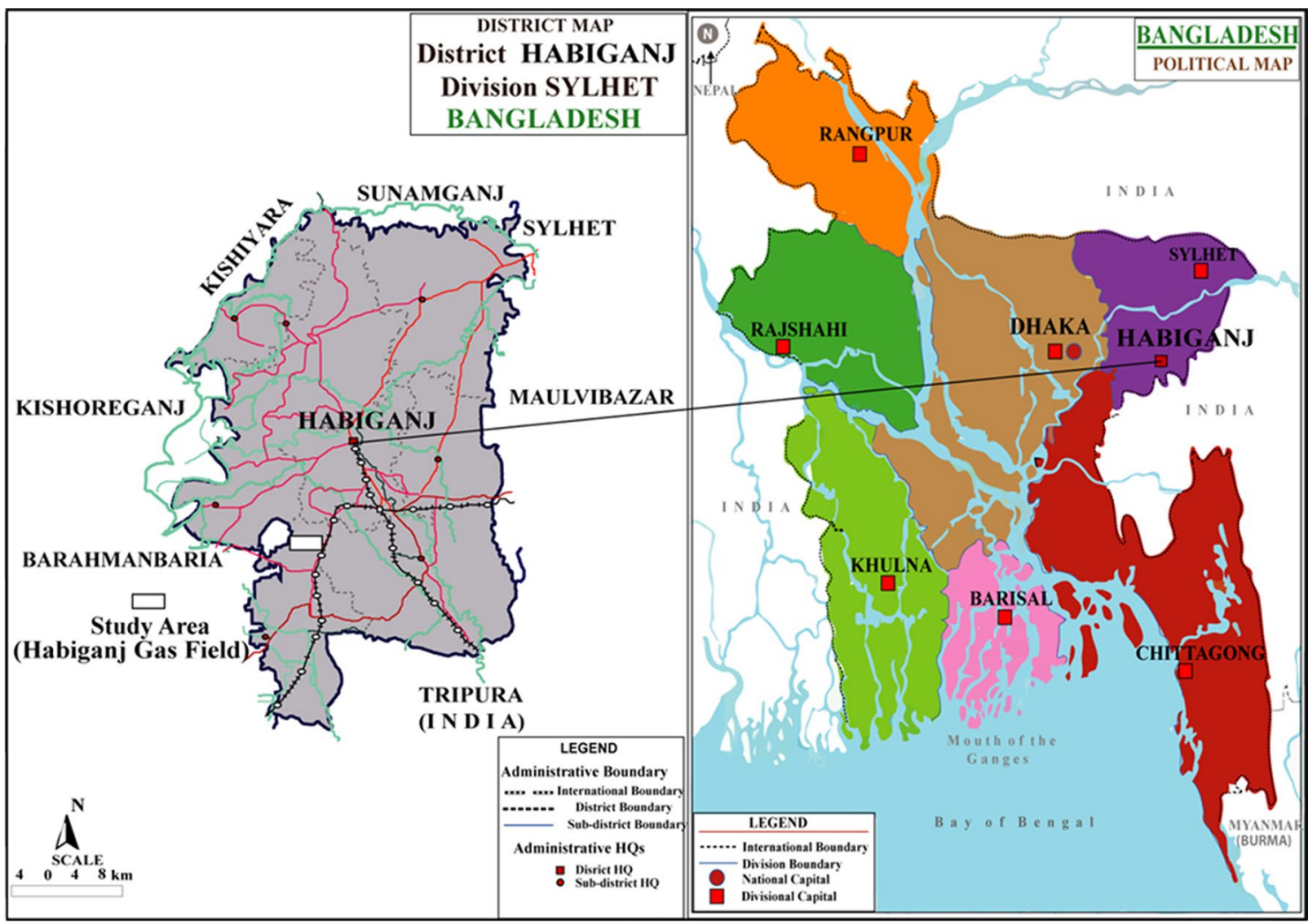

Fig. 1 Location map of the study area of Habiganj gas field, Bangladesh (modified after LGED 1999; Shofiqul and Nusrat 2013) 
field, the largest reserved gas field in Bangladesh, lies about $32 \mathrm{~km}$ southwestern of this gas field (Imam 2013; Rahman et al. 2017). The Surma Basin is a dynamically subsiding sub-basin of the Bengal Basin situated in the northeastern part of Bangladesh, and HGF occupies in the southern part of the Surma Basin. It is shaped by a north-south prolonged anticline, which lies in the northernmost termination of the $130 \mathrm{~km}$ long Baramura anticlinal and lineated from Tripura (India) in the south. The structure has a four-way closure, and the gas water content level in the closure is $11.5 \mathrm{~km}$ long and $4.5 \mathrm{~km}$ wide. Near the central part of the structure, the dip angles of the western and eastern flank of the Habiganj anticline are $10^{\circ}$ and $9^{\circ}$, respectively (Imam 2013; Islam et al. 2017).

The UGS and LGS are the two gas-bearing zones in the reservoirs consisting of sandstones having a place with the Surma Group of Miocene-Pliocene age. The UGS is the primary gas reservoir that lies at a profundity of $1320 \mathrm{~m}$ underneath the surface and maximum gross pay of $230 \mathrm{~m}$ thick. The reservoir formation of UGS is characterized by medium to fine-grained sand, very much well-sorted, perfect and unconsolidated. Among the 11 producing well, HBJ06 is a vertical well, producing the gas vertically from the UGS zone (Fig. 2). Through HBJ-6, the UGS reservoir can be characterized as: porosity of $30 \%$, average permeability of $3500 \mathrm{mD}(2000-4000 \mathrm{mD})$, water saturation of $40 \%$ and reservoir pressure of 2076 psia (Petrobangla 2011; Imam 2013; Shofiqul and Nusrat 2013). The water drive mechanism dominates the gas recovery from the UGS, and the aquifer is ten times extensive than the reservoir (Haq and Gomes 2001).

The HGF is one of the largest gas-producing gas fields in Bangladesh, which was discovered by Shell Oil Company in 1963, and gas production was started in February 1969. At the first stage, the production was quite low and fluctuated; however, the rate was increased to about 25 MMscfd from the first two wells in 1981. Afterward, the more wells were drilled in different stages and the production was increased gradually. In May 2004, production crossed 300 MMscfd marks from 11 producing wells and this rate continued for about 6 months, and then it started to decline. In December 2009, field production was $226 \mathrm{MMscfd}$ and a total of $1671 \mathrm{Bscf}$ has been produced from this gas field (Gustafson Associates 2011). In 1992 evaluated by IKM, the GIIP of the HGF was 3.66 Tcf with 51.64\% recovery factor, along these lines recording an initial gas reserve 1.89 Tcf. In 2003, HCU-NPD reevaluated the GIIP at 5.13 Tcf with a $75.05 \%$ recovery factor; in this manner, recording an initial
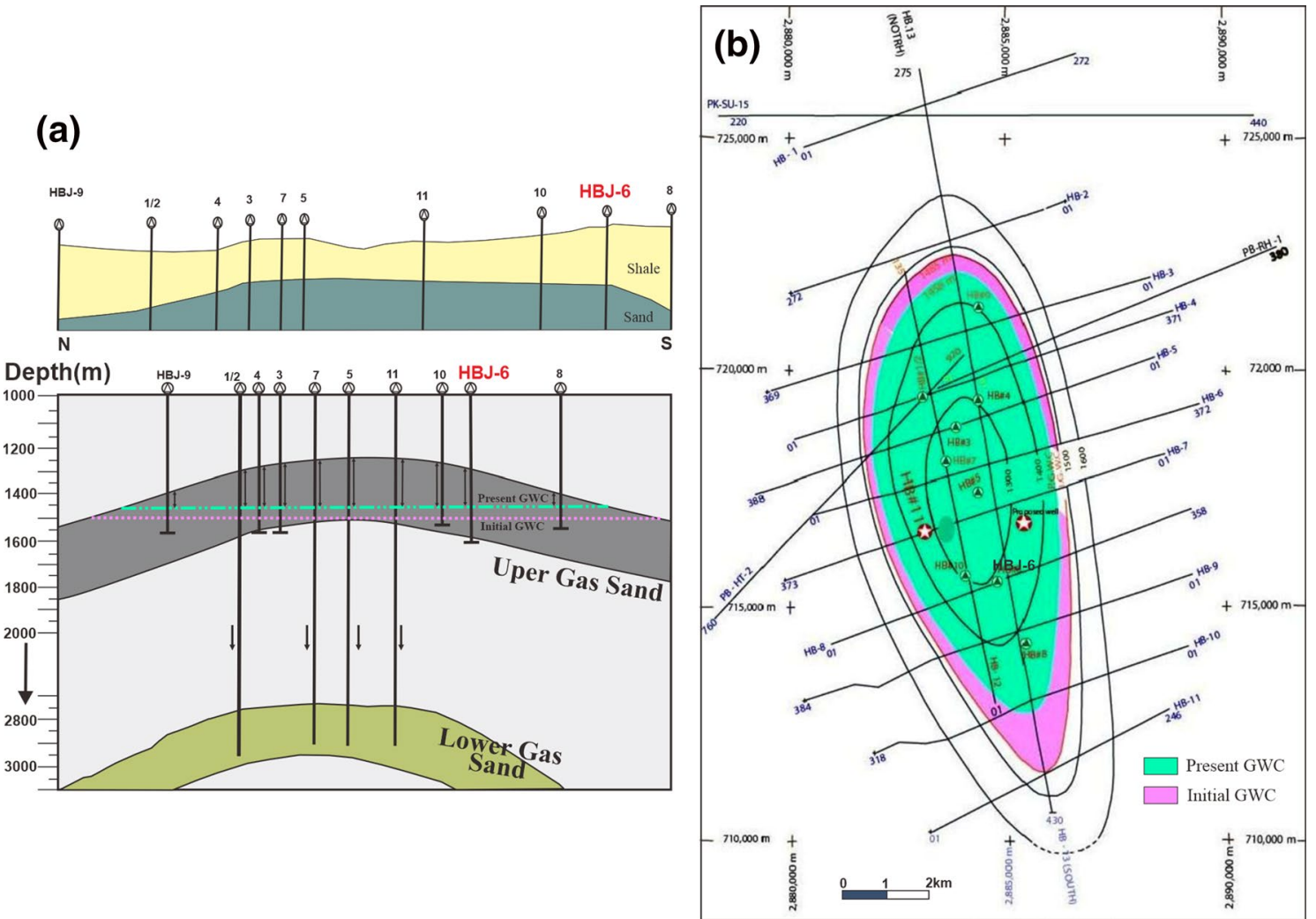

Fig. 2 a Cross-sectional view and $\mathbf{b}$ the depth structure on top of upper gas sand of the subsurface formations and the position of wells of the Habiganj gas field, Bangladesh (Imam 2013; Rahman et al. 2017; Gustafson Associates 2011) 
gas reserve was 3.85 Tcf. Finally, in 2011, Petrobangla published a revised estimate of the gas field based on RPS estimated GIIP of $3.68 \mathrm{Tcf}$ with a suggested $71.47 \%$ recovery (Petrobangla 2011; Imam 2013; Shofiqul and Nusrat 2013).

\section{Materials and method}

For this study, production, well performance and reservoir data were collected from BGFCL through Petrobangla and annual reports of BGFCL (Petrobangla 2011; Rahman and Akter 2014; BGFCL 2016). The Nodal analysis approach was utilized through the generation of the IPR-VLP curves based on the production data. This method may be utilized to determine locations of excessive flow resistance or pressure drop in any part of the framework (Coles 1965; Haq et al. 2003; Jansen and Currie 2004; Wan 2011). Nodal analysis is not only used to optimize the production; it is also a strategy to find out the stabilized flow rate for a given arrangement of conditions (Ravindran and Horne 1993; Boyun et al. 2007; Christopher and Uche 2014). In this approach, the AOF/TPC analysis by the reservoir model and AOF/TPC analysis by Rawlins-Schellhardt (P2) model have been used to evaluate gas production optimization in the HGF by using F.A.S.T. VirtuWell ${ }^{\mathrm{TM}}$ software. At a specific time in the life of the well, there are always two pressures that remain fixed and are not the function of the flow rate. One of these pressures is the average reservoir pressure, and the other is the system outlet pressure, usually used as the separator pressure (Hossain 2008; Midthun et al. 2015). The Nodal analysis approach is based on the following criteria:

\section{AOF (IPR curves) analysis}

In AOF analysis, the IPR curve was generated by the data of reservoir parameters, including porosity, water saturation, permeability, reservoir pressure, drainage area, IGIP, perforation angle, skin factor, etc., in the F.A.S.T VirtuWell ${ }^{\mathrm{TM}}$ software. IPR or back-pressure bend is characterized as the functional relationship between the production rate from the reservoir and the bottom-hole flowing pressure. IPR is described in the pressure range between the average reservoir pressure and atmospheric pressure (Economides et al. 2013; Affanaambomo 2008; Tan et al. 2014; Vieira 2015). The inflow performance of a well significantly depends on various factors like the sort of reservoir, drive mechanism, reservoir pressure, permeability, etc. (Schlumberger 2000; Ruysschaert 2012).

At that point shows the production rate as an element of the bottom-hole pressure. The graphical representation of IVR is based on the flowing pressure $\left(P_{\mathrm{wf}}\right)$, and production rate $(q)$ can be calculated by the following equation (Economides et al. 2013; Sylvester et al. 2015):

$P_{\mathrm{i}}^{2}-P_{\mathrm{wf}}^{2}=\frac{1424 Z T}{k h}\left(\ln \frac{0.472 r_{\mathrm{e}}}{r_{\mathrm{w}}}+s\right) q+\frac{1424 Z T}{k h} q^{2}$.

\section{TPC (VLP curves) analysis}

In TPC analysis, the wellbore properties data such as tubing data, wellhead pressure, casing data, liquid ratios and flow path were used in F.A.S.T. VirtuWell ${ }^{\mathrm{TM}}$ software to construct the VLP curves, which depicts how the pressure drop influences the flow rate that achieves the surface in the tubing. Vertical flow performance is the well capacity to deliver under a consistent surface pressure limitation. In a producing well, this is called tubing intake or outflow performance (Economides et al. 2013; Affanaambomo 2008; Ruysschaert 2012).

$P_{\mathrm{wf}}=P_{\mathrm{tf}}+\Delta p_{\text {total }}$

where $\Delta p_{\text {total }}=\Delta p_{\mathrm{f}}+\Delta p_{\mathrm{p}}+\Delta p_{\mathrm{k}}=$ frictional pressure loss + potential pressure loss + kinetic pressure loss.

For multiphase flow, the forecast of the pressure drop profile is affected by the phase behavior and properties, flowing temperature, flow pattern and mechanical losses. The most widely recognized analysis method of this performance begins with the fixed back pressure (indicated by wellhead or separator pressure), and the pressure losses of the flowing bottom-hole pressure can be measured (Aziz and Govier 1972; Govier and Fogarasi 1975; Economides et al. 2013; Rahman and Akter 2014; Ruysschaert 2012). The connections of multiphase pressure loss correlations depend on the mathematical statement of the Fanning friction pressure loss (Sylvester et al. 2015). It can be assembled by considering several flow patterns as Beggs and Brill (1973) correlation, Petalas and Aziz model (1998) and non-flow patterns as Gray (1978) and Hagedorn and Brown (1965) correlation (Oddie et al. 2003; Abhari et al. 2010; Ottba and Al-Jawad 2006; Ahmed and Ayoub 2014; CheGuide 2015). The empirical model developed by Beggs and Brill (1973) has been selected for the multiphase flow pressure drop calculations in this study.

\section{The determination of well deliverability and operating points}

The well deliverability is the ability of fluid flow at a constant rate by a particular well, whereas the intersection of the curves is the operating point (or natural flow point) that can be determined by the combination of IPR and VLP curves (Boyun et al. 2007; Okoro and Ossia 2015; Vieira 2015). The gas production is directly involved to the well deliverability, 
where the gas production increases proportional with well deliverability (Economides et al. 2013; Jansen and Currie 2004; Rahman and Akter 2014; Shah and Hossain 2015). The operating points are measured by the interaction of $\mathrm{AOF}$ and TPC curves in the F.A.S.T. VirtuWell ${ }^{\mathrm{TM}}$ software, which is indicated the well deliverability from Nodal analysis.

\section{AOF/TPC analysis by F.A.S.T. VirtuWell ${ }^{\mathrm{Tm}}$ software}

In AOF/TPC analysis in reservoir model, casing data, tubing data, perforation data, wellbore properties, TPC data, specific different tubing scenarios data and fluid properties are entered into the input feed of F.A.S.T. VirtuWell ${ }^{\mathrm{TM}}$ software. AOF curves and gas AOF/TPC curves were automatically produced based on the inputted data. This gas AOF/ TPC curve represents the relationship in the form of pressure versus flow rate graph, and the operating point can be determined from the intersection of TPC and AOF curves. Additionally, TPC data specify different tubing scenarios data; reservoir AOF data were also inputted into the software for AOF/TPC analysis in Rawlins-Schellhardt (P2) model, where IPR-VLP curves were also automatically generated. The operating points and the resulting intersection points of the curves (Fig. 3b, d) are shown in Tables 2 and 3. Fetkovich's equation for gas reservoirs is one of the most common equations for gas rate prediction used as the back-pressure equation in the software (Maurer Engineering 1994). The equation is denoted as:

$Q_{\mathrm{g}}=c\left(P_{\mathrm{r}}^{2}-P_{\mathrm{wf}}^{2}\right)^{n}$.

\section{Results and discussion}

Generally, matrix acidizing, hydraulic fracturing, acid fracturing, changing the diameter of tubing and chokes, gas injection, water injection, changing wellhead pressure, increasing perforation, changing well direction, etc., are used to maximize the production of oil and/or gas. The HGF can be characterized as a high-performance reservoir with large permeability and strong water drive (Ravindran and Horne 1993; Bieker et al. 2006; Dehua et al. 2011). Therefore, hydraulic fracturing, acid fracturing, gas injection or water injection methods are not necessary for this field. However, the production can be enhanced by changing the condition of the controlling parameters in different nodes of a particular well by the Nodal analysis approach.

The diameter of HBJ-06 (the well no. 06 of HGF) is only $3.5^{\prime \prime}$, perforation height is $430 \mathrm{ft}(131.06 \mathrm{~m})$, whereas the pay zone is $800 \mathrm{ft}(243.84 \mathrm{~m})$. Due to the drilling and
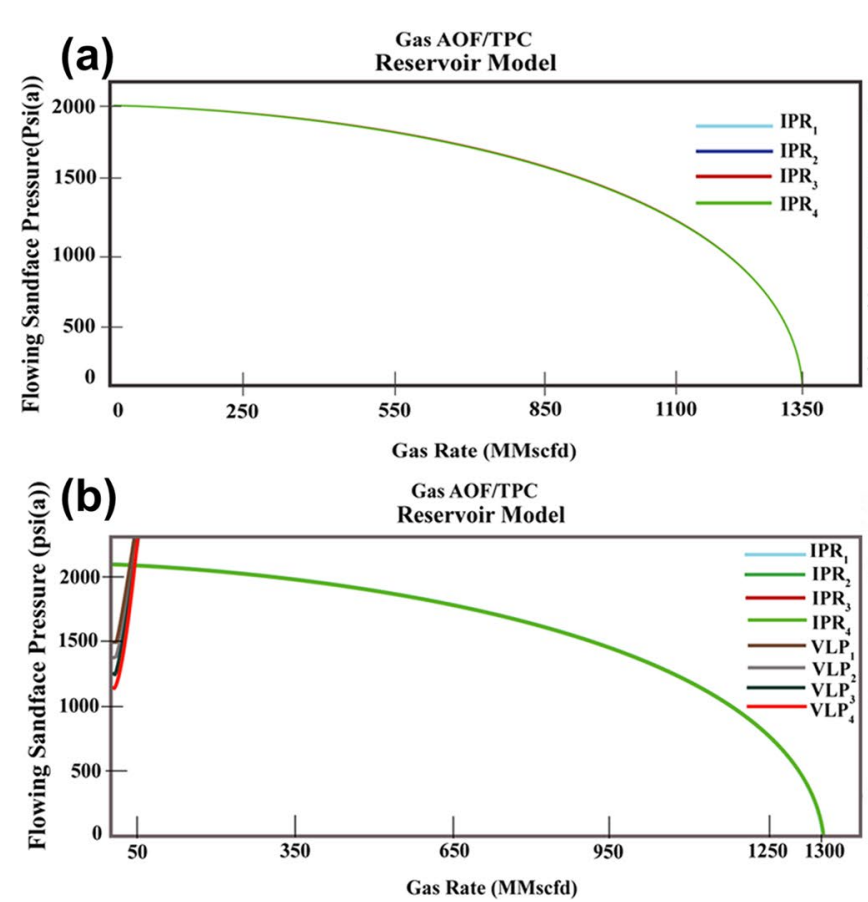

Fig. 3 a IPR and b IPR-VLP curves generated by reservoir model, c VLP and $\mathbf{d}$ IPR-VLP curves generated by the Rawlins-Schellhardt (P2) model, by using AOF/TPC analysis for the HBJ-06 well of the Habiganj gas field. The different IPR curves $\left(\mathrm{IPR}_{1}, \mathrm{IPR}_{2}, \mathrm{IPR}_{3}\right.$ and
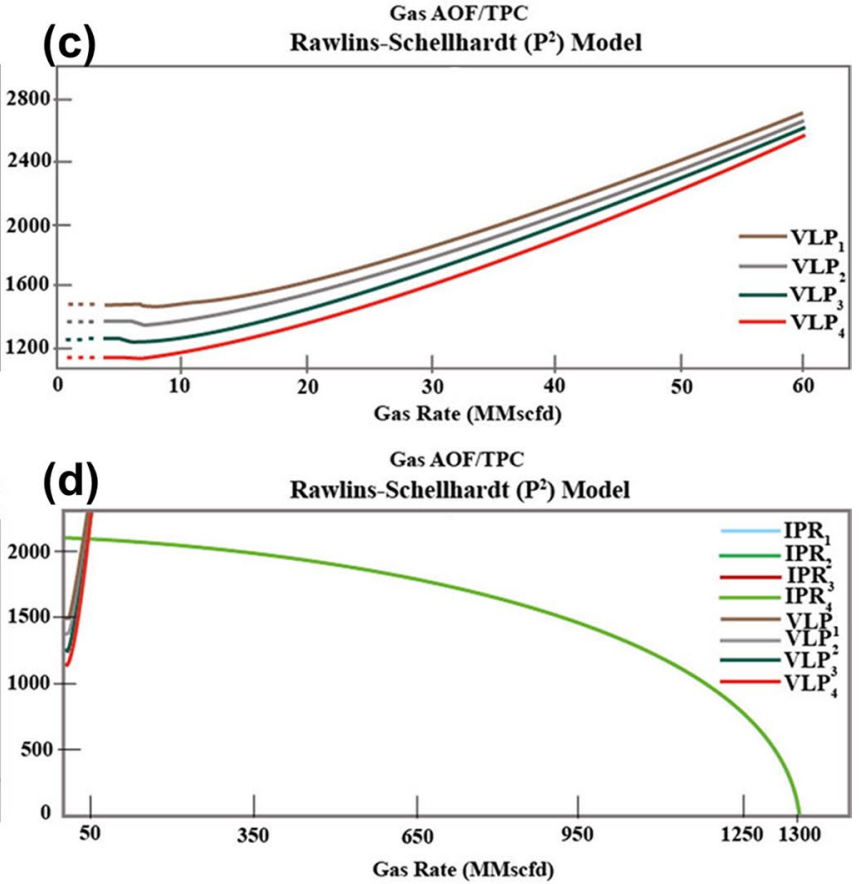

$\mathrm{IPR}_{4}$ ) are overlapped with each other due to the very close values of production rate and flowing pressure. Additionally, the different VPL curves $\left(\mathrm{VLP}_{1}, \mathrm{VLP}_{2}, \mathrm{VLP}_{3}\right.$ and $\left.\mathrm{VLP}_{4}\right)$ of the tubing $A, B, C$ and $D$ are indicated by the different colors 
continuous production, the skin is produced near the wellbore, which value is 8 . The average reservoir pressure is 2076 psia, sandface temperature is $113{ }^{\circ} \mathrm{C}$, and the average wellhead pressure is 1404.70 psia. The values of gas gravity, $\mathrm{N}_{2}$ and $\mathrm{CO}_{2}$ are $0.56 \%, 0.38 \%$ and $0.07 \%$, respectively. Presently, the daily gas production rate of HBJ-06 is 14.963 MMscfd (for details BGFCL 2016). So, considering all the factors, the production can be enhanced by reduction in the wellhead pressure of HBJ-06 associated while keeping the other factors unchanged.

\section{Operating points in AOF/TPC analysis in the reservoir model}

In the AOF in the reservoir model, the IPR curves presented in Fig. 3a are initially constructed by the reservoir parameters of HBJ-06 using F.A.S.T. VirtuWell ${ }^{\mathrm{TM}}$ software mentioned as IPR $1, \mathrm{IPR}_{2}, \mathrm{IPR}_{3}$ and $\mathrm{IPR}_{4}$ designating different wellhead pressure (Shah et al. 2014; Shah and Hossain 2015). During the TPC analysis, several tubing configurations were suggested which are designated as A, B, C and $\mathrm{D}$; however, they exhibited almost similar patterns (Table 1). At the same time, it is primarily investigated VLP curves in Fig. $3 \mathrm{~b}$ in the TPC analysis, which is generated by the production wellbore parameters stated as $\mathrm{VLP}_{1}, \mathrm{VLP}_{2}, \mathrm{VLP}_{3}$ and $\mathrm{VLP}_{4}$ to keeping the tubing parameters unchanged (Shah et al. 2014; Shah and Hossain 2015).

Additionally, the result of the AOF/TPC reservoir model is obtained from the intersection points, which are known as operating points, presented in Table 2 . The operating points value are 38.481, 40.993, 43.153 and 46.016 MMscfd, respectively, which are generated by $\mathrm{IPR}_{1}, \mathrm{IPR}_{2}, \mathrm{IPR}_{3}$ and
$\mathrm{IPR}_{4}$ with the respective sandface flowing pressures of 2070.4, 2070.1, 2069.7 and 2069.5 psi(a) against $\mathrm{VLP}_{1}$, $\mathrm{VLP}_{2}, \mathrm{VLP}_{3}$ and $\mathrm{VLP}_{4}$ curves with wellhead pressures of $1300,1200,1100$ and 1000 psi(a), respectively, that are the relationship in the form the graph of pressure versus flow rate (Fig. 3b). The values of different operating points of 38.481, 40.993, 43.153 and 46.016 MMscfd indicate the flow rate points that are mentioned as the well deliverability in different pressures conditions (Economides et al. 2013; Shah et al. 2014; Shah and Hossain 2015; Vieira 2015).

\section{Operating points in Rawlins-Schellhardt (P2) model}

The result of the AOF/TPC analysis in the Rawlins-Schellhardt (P2) model is obtained from the intersection points (operating points) of AOF and TPC curves (Table 3). In the Rawlins-Schellhardt (P2)-type curve analysis, it is initially investigated by VLP curves $\left(\mathrm{VLP}_{1}, \mathrm{VLP}_{2}, \mathrm{VLP}_{3}\right.$ and $\mathrm{VLP}_{4}$ ) demonstrating the values of $1300,1200,1100$ and 1000 psi(a), respectively (Fig. 3c), that are intersected with IPR curves $\left(\mathrm{IPR}_{1}, \mathrm{IPR}_{2}, \mathrm{IPR}_{3}\right.$ and $\mathrm{IPR}_{4}$ ) with the respective sandface pressures of 2070.4, 2070.1, 2069.7 and 2069.5 psi(a) and it is formed in the relationship of pressure versus flow rate curves (Fig. $3 \mathrm{~d}$ ). The flow rates in the intersecting point of IPR and VLP curves are the well deliverability, and the calculated respective values of the operating points are found as 38.481, 40.993, 43.153 and 46.016 MMscfd (Shah et al. 2014; Shah and Hossain 2015; Vieira 2015). The respective well deliverability rates are very close to that of Table 2 , indicating the gas production rate is higher than the present gas production rate of 14.963 MMscfd.
Table 1 The gas TPC data of the HBJ-6

\begin{tabular}{llllllll}
\hline TPC & $\begin{array}{l}\text { Wellhead } \\
\text { pressure, } \\
\text { psi(a) }\end{array}$ & $\begin{array}{l}\text { CGR/OGR, } \\
\text { bbl/MMscf }\end{array}$ & $\begin{array}{l}\text { WGR, bbl/ } \\
\text { MMscf }\end{array}$ & ID, in. & OD, in. & Length, ft (CF) & MD, ft (CF) \\
\hline A & 1300 & 0.1 & 0.2 & 3.28 & 3.5 & 4552 & 4552 \\
B & 1200 & & & & & & \\
C & 1100 & & & & & \\
D & 1000 & & & & & \\
\hline
\end{tabular}

Table 2 Operating points result at reservoir AOF/TPC-type curves analysis for HBJ-06 (pressure vs. flow rate)

\begin{tabular}{lllllllll}
\hline AOF & $P_{\mathrm{SF}} A$ psi(a) & $Q_{\mathrm{G}} A$ MMscfd & $P_{\mathrm{SF}} B$ psi(a) & $Q_{\mathrm{G}} B$ MMscfd & $P_{\mathrm{SF}} C$ psi(a) & $Q_{\mathrm{G}} C$ MMscfd & $P_{\mathrm{SF}} D$ psi(a) & $Q_{\mathrm{G}} D$ MMscfd \\
\hline 1 & 2070.4 & 38.481 & 2070.1 & 40.993 & 2069.7 & 43.153 & 2069.5 & 46.016 \\
2 & 2070.4 & 38.481 & 2070.1 & 40.994 & 2069.8 & 43.153 & 2069.5 & 46.016 \\
3 & 2070.4 & 38.481 & 2070.1 & 40.994 & 2069.8 & 43.154 & 2069.5 & 46.017 \\
4 & 2070.4 & 38.482 & 2070.1 & 40.994 & 2069.8 & 43.154 & 2069.5 & 46.017 \\
\hline
\end{tabular}

$P_{\mathrm{SF}} A, P_{\mathrm{SF}} B, P_{\mathrm{SF}} C$ and $P_{\mathrm{SF}} D$ are the optimized sandface flowing pressure, and $Q_{\mathrm{G}} A, Q_{\mathrm{G}} B, Q_{\mathrm{G}} C$ and $Q_{\mathrm{G}} D$ are the optimized gas flow rate in tubing $A, B, C$ and $D$, respectively 
Table 3 Operating points result at Rawlins-Schellhardt $\left(P^{2}\right)$ AOF/TPC-type curve analysis for HBJ-06 (pressure vs. flow rate)

\begin{tabular}{lllllllll}
\hline AOF & $P_{\mathrm{SF}} A, \mathrm{psi}(\mathrm{a})$ & $Q_{\mathrm{G}} A$, MMscfd & $P_{\mathrm{SF}} B, \mathrm{psi}(\mathrm{a})$ & $Q_{\mathrm{G}} B$, MMscfd & $P_{\mathrm{SF}} C, \mathrm{psi}(\mathrm{a})$ & $Q_{\mathrm{G}} C, \mathrm{MMscfd}$ & $P_{\mathrm{SF}} D, \mathrm{psi}(\mathrm{a})$ & $Q_{\mathrm{G}} D, \mathrm{MMscfd}$ \\
\hline 1 & 2070.4 & 38.481 & 2070.1 & 40.993 & 2069.7 & 43.153 & 2069.5 & 46.016 \\
2 & 2070.4 & 38.481 & 2070.1 & 40.993 & 2069.7 & 43.153 & 2069.5 & 46.016 \\
3 & 2070.4 & 38.481 & 2070.1 & 40.993 & 2069.7 & 43.153 & 2069.5 & 46.016 \\
4 & 2070.4 & 38.481 & 2070.1 & 40.993 & 2069.7 & 43.153 & 2069.5 & 46.016 \\
\hline
\end{tabular}

$P_{\mathrm{SF}} A, P_{\mathrm{SF}} B, P_{\mathrm{SF}} C$ and $P_{\mathrm{SF}} D$ are the optimized sandface flowing pressure, and $Q_{\mathrm{G}} A, Q_{\mathrm{G}} B, Q_{\mathrm{G}} C$ and $Q_{\mathrm{G}} D$ are the optimized gas flow rate in tubing $A, B, C$ and $D$, respectively

\section{Comparison between reservoir and $\mathrm{P} 2$ types of analytical results}

In AOF/TPC analysis in reservoir model, the initially generated IPR and VLP curves by the reservoir parameters of HBJ-06 mentioned as IPR $, \mathrm{IPR}_{2}, \mathrm{IPR}_{3}$ and IPR and $\mathrm{VLP}_{1}, \mathrm{VLP}_{2}, \mathrm{VLP}_{3}$ and $\mathrm{VLP}_{4}$ (Fig. 3a) represent the inclination of the reservoir pressure which is formed by the inflow of the node (Beggs 1984; Jansen and Currie 2004; Hossain 2008). On the other hand, VLP curves are generated by the production wellbore properties stated as $\mathrm{VLP}_{1}, \mathrm{VLP}_{2}, \mathrm{VLP}_{3}$ and $\mathrm{VLP}_{4}$ at the early stage of AOF/ TPC analysis in Rawlins-Schellhardt (P2) model (Fig. 3b), which represent the gas production rate through tubing that is formed by the outflow of the node (Beggs 1984; Hossain 2008). In the AOF/TPC analysis in reservoir model, these IPR curves are intersected with VLP curves while AOF/ TPC analysis in Rawlins-Schellhardt (P2) model VLP curves are also intersected with IPR curves (Figs. 3b, d), which concurrently represent as a form of Nodal analysis technique (Ibelegbu 2004). Both IPR and VLP curves are generated at the same time through double analyses (Beggs 1984, 1991; Economides et al. 2013; Jansen and Currie 2004; Hossain 2008; Midthun et al. 2015). Therefore, both of these curve analysis indicating wellhead pressure have decreased with the decrease in respective reservoir pressure (Fig. 4; Table 4; Mogensen 1991; Economides et al. 2013). Through the comparison between the AOF/TPC analysis in the reservoir model and Rawlins-Schellhardt (P2) model for HBJ-06, it is apparent that operating points in both models are similar. This analysis demonstrated that the gas-producing rates increase as $38.481,40.993,43.153$ and 46.016 MMscfd for the respective wellhead pressures of 1300,1200, 1100 and $1000 \mathrm{psi}(\mathrm{a})$ and the reservoir pressures of 2070.4, 2070.1, 2069.7 and 2069.5 psi(a). The optimized gas production rates are formed in a rising upward curve, which indicates the increase in gas production rate with the declination of wellhead and reservoir pressure (Fig. 4).

The suggested vertical wellbore configuration of the HBJ-06 is presented in Fig. 5, which is generated by using
F.A.S.T. VirtuWell ${ }^{\mathrm{TM}}$ software in the optimized conditions. The TMD is $4980 \mathrm{ft}(1518 \mathrm{~m})$ with the casing plug total bottom depth of $5515 \mathrm{ft}(1681 \mathrm{~m})$, the midpoint of perforation (MPP) of $4740 \mathrm{ft}(1444.5 \mathrm{~m})$ and datum depth $4765 \mathrm{ft}$ (1452 m) (Fig. 5). It is mentioned that the depth (4765 ft) of the MPP is mainly related to the EOT depth. In this configuration, EOT is above the MPP, where the fluid flow is within the casing until it reaches to the EOT point. However, the tubing with casing ID calculation in this study showed the datum depth of $4765 \mathrm{ft}$ (1452 m). It is a reference point for the calculations that are either derived from the sandface to the datum and/or from the datum to the wellhead (Table 5).

\section{Liquid lift ratio}

The effect of the increasing liquid rate is due to the increase in both liquids holdup and fluid velocity. This will cause an increase in both the hydrostatic and friction losses. CGR is the condensate to gas ratio produced at the surface, which is usually calculated from direct measurements diving by daily gas rate to the known daily condensate. Besides this, the CGR is also used to calculate the "Recombined Gas Gravity" and the "Recombined Gas Rate," which are further used to calculate the wellbore pressure drop (Beggs 1991; Ibrahim 2007; Jaf 2015). Similarly, the CWR has

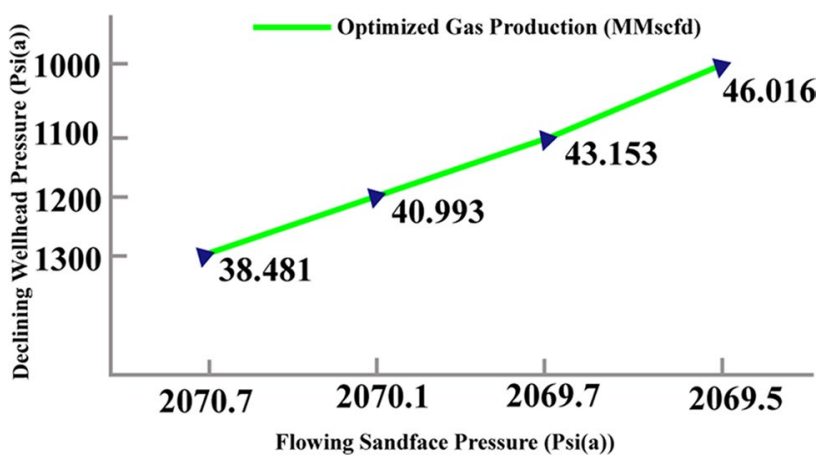

Fig. 4 The optimized gas production rate of the HBJ-06 
Table 4 Optimized gas production in different pressure conditions derived from the comparison of the reservoir model and RawlinsSchellhardt $\left(P^{2}\right)$ model

\begin{tabular}{lll}
\hline $\begin{array}{l}\text { Flowing sandface pres- } \\
\text { sure, psi(a) }\end{array}$ & $\begin{array}{l}\text { Declining wellhead } \\
\text { pressure, psi(a) }\end{array}$ & $\begin{array}{l}\text { Optimized } \\
\text { gas produc- } \\
\text { tion, MMscfd }\end{array}$ \\
\hline 2070.4 & 1300 & 38.481 \\
2070.1 & 1200 & 40.993 \\
2069.7 & 1100 & 43.153 \\
2069.5 & 1000 & 46.016 \\
\hline
\end{tabular}

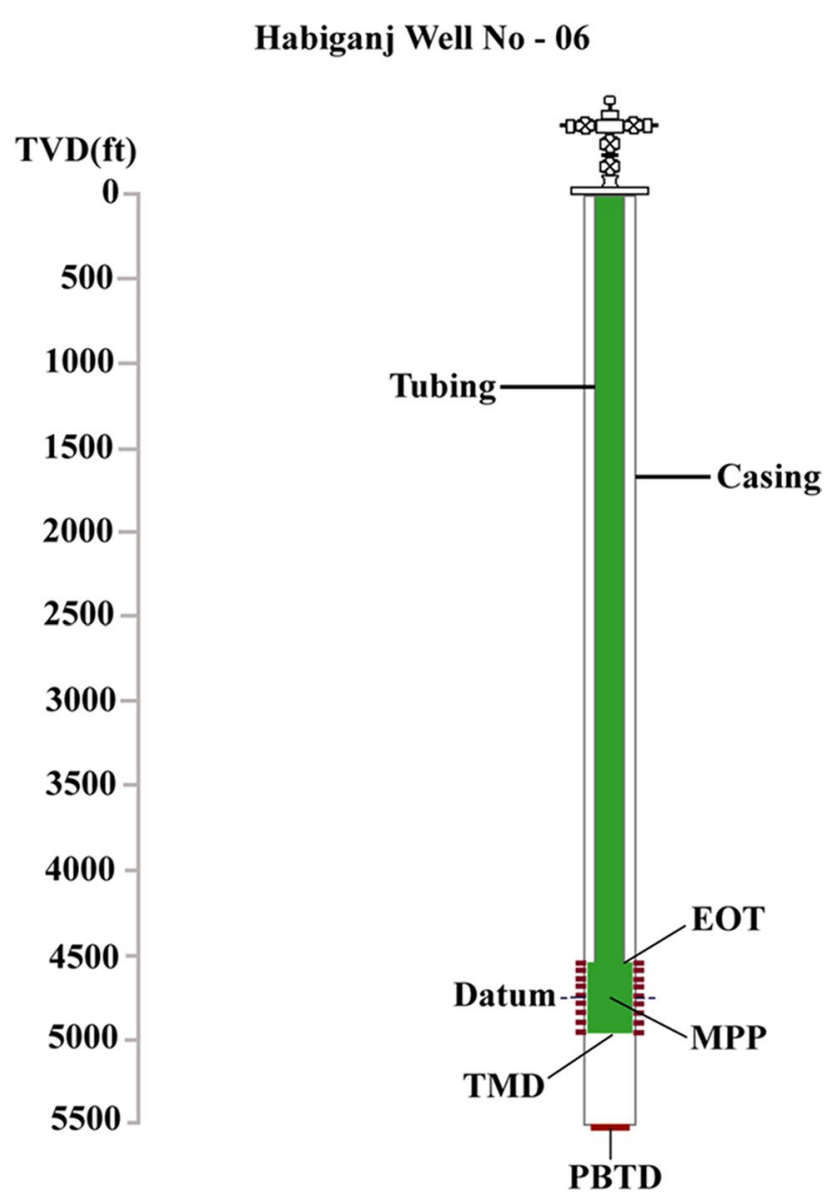

Fig. 5 Schematic diagram of vertical wellbore configuration in the optimum condition of HBJ-06

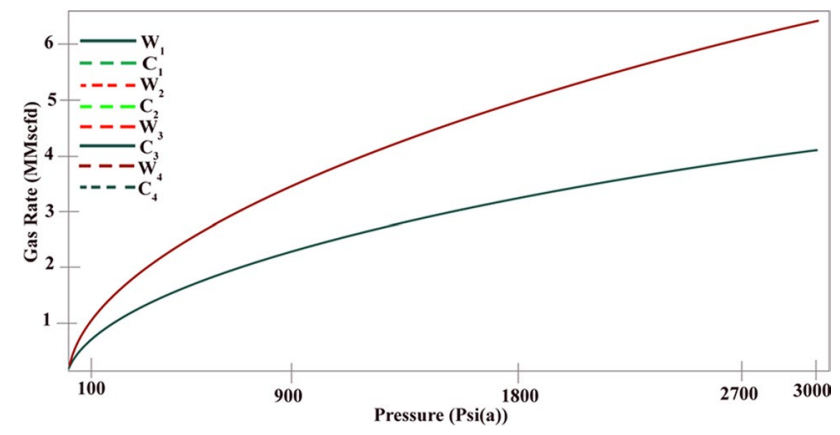

Fig. 6 The liquid lift ratio in the optimum condition of the HBJ-06, where $C_{1}, C_{2}, C_{3}$ and $C_{4}$ curves represent the minimum gas rate to lift condensate and $W_{1}, W_{2}, W_{3}$ and $W_{4}$ curves, minimum gas rate to lift water in different wellhead pressure condition. The different curves $\left(C_{1}, C_{2}, C_{3}\right.$ and $C_{4}$ or $W_{1}, W_{2}, W_{3}$ and $\left.W_{4}\right)$ are overlapped with each other due to the very close values of production rate and flowing pressure

also been calculated. For the measurement of the liquid lift ratio of the vertical wellbore, the fluid properties, using tubing data, tubing pressure and temperature, have been considered (Maurer Engineering 1994). Previously, the HBJ-06 wellbore the CGR and CWR was calculated as 0.05 and 0.11 , respectively (BGFCL 2016). Taking same tubing sizes of HBJ-06 well with the suggesting wellhead pressure 1300, 1200, 1100 and 1000 psi(a) in F.A.S.T VirtuWell ${ }^{\mathrm{TM}}, C_{1}, C_{2}, C_{3}$ and $C_{4}$ curves and $W_{1}, W_{2}, W_{3}$ and $W_{4}$ curves are generated, which are mention, respectively, for the minimum gas rate to lift condensate and minimum gas rate to lift water for this tubing (Fig. 6). The respective values of these $C_{1}, C_{2}, C_{3}$ and $C_{4}$ curves are 2.776, 2.661, 2.541, $2.415 \mathrm{MMscfd}$, and $W_{1}, W_{2}, W_{3}$ and $W_{4}$ curves are $4.321,4.139,3.949,3.751$ MMscfd (Table 6). Finally, it has been measured based on the optimizing conditions that the respective CGRs are 0.07, 0.06, 0.06 and 0.05, and CWRs are $0.11,0.10,0.09$ and 0.08 for the suggesting wellhead pressure. Consequently, it is observed that the values of CWR have gradually decreased, although there is no significant change in the values of CGR due to the declination of wellhead pressures.

Table 5 Evaluation of natural gas production results of the HBJ-06, Habiganj gas field, Bangladesh

\begin{tabular}{lllllll}
\hline Well No. & $\begin{array}{l}\text { Reservoir pres- } \\
\text { sure, psi(a) }\end{array}$ & $\begin{array}{l}\text { Average wellhead } \\
\text { pressure, psi(a) }\end{array}$ & $\begin{array}{l}\text { Production } \\
\text { rate, MMscfd }\end{array}$ & $\begin{array}{l}\text { Flowing sandface } \\
\text { pressure, psi(a) }\end{array}$ & $\begin{array}{l}\text { Suggesting wellhead } \\
\text { pressure, psi(a) }\end{array}$ & $\begin{array}{l}\text { Optimized } \\
\text { gas produc- } \\
\text { tion, MMscfd }\end{array}$ \\
\hline HBJ-06 & 2076 & 1404.7 & 14.963 & 2070.4 & 1300 & 38.481 \\
& & & & 2070.1 & 1200 & 40.993 \\
& & & 2069.7 & 1100 & 43.153 \\
\end{tabular}


Table 6 Optimized liquid lift ratio of the HBJ-06

\begin{tabular}{llllll}
\hline Test & Tubing ID, in. & $\begin{array}{l}\text { Wellhead pres- } \\
\text { sure, psi(a) }\end{array}$ & $\begin{array}{l}\text { Temperature, } \\
{ }^{\circ} \mathrm{F}\end{array}$ & $Q_{\mathrm{w}}$ (water), MMscfd & $\begin{array}{l}Q_{\mathrm{c}} \text { (conden- } \\
\text { sate), MMscfd }\end{array}$ \\
\hline 1 & 3.5 & 1300 & 100 & 4.321 & 2.776 \\
2 & 3.5 & 1200 & 100 & 4.139 & 2.661 \\
3 & 3.5 & 1100 & 100 & 3.949 & 2.541 \\
4 & 3.5 & 1000 & 100 & 3.751 & 2.415 \\
\hline
\end{tabular}

\section{Conclusions}

This study was carried out to attempt an application of the Nodal analysis approach to optimize the natural gas production of HBJ-06 of the HGF, Bangladesh. The HBJ-06 is one of the major gas-producing wells of the HGF with a current production rate of $14.963 \mathrm{MMscfd}$. The Nodal analysis technique identifies each component as a resistance in the system, starting from the reservoir to the outlet pressure of the separator while analyzing IPR and VLP curves for the vertical wellbore. Following the Nodal analysis by F.A.S.T. Virtu Well ${ }^{\mathrm{TM}}$ software package, the results are briefly summarized as follows:

- The daily gas production capacity is optimized to 38.481 , 40.993, 43.153 and 46.016 MMscfd by suggesting the respective declined wellhead pressure of 1300, 1200, 1100 and 1000 psi(a) without any significant change of the tubing diameter and skin factor.

- The optimized CGRs are 0.07, 0.06, 0.06 and 0.05, as well as CWRs are $0.11,0.10,0.09$ and 0.08 , respectively.

Based on this study, the production can be enhanced by the decline of wellhead pressure. The economic analysis was not included in the scope of this study. So advance study, economic analysis and strategic planning must be considered before implementing this technique.

Open Access This article is licensed under a Creative Commons Attribution 4.0 International License, which permits use, sharing, adaptation, distribution and reproduction in any medium or format, as long as you give appropriate credit to the original author(s) and the source, provide a link to the Creative Commons licence, and indicate if changes were made. The images or other third party material in this article are included in the article's Creative Commons licence, unless indicated otherwise in a credit line to the material. If material is not included in the article's Creative Commons licence and your intended use is not permitted by statutory regulation or exceeds the permitted use, you will need to obtain permission directly from the copyright holder. To view a copy of this licence, visit http://creativecommons.org/licenses/by/4.0/.

\section{References}

Abhari MN, Ghodsian M, Vaghefi Panahpur N (2010) Experimental and numerical simulation of flow in a $90^{\circ}$ bend. Flow Meas Instrum 21(3):292-298. https://doi.org/10.1016/j.flowmeasin st.2010.03.002
Affanaambomo BO (2008) Study of tapered internal diameter tubing string well completion for enhanced production. Post Graduate Dissertation, Petroleum Engineering, Texas Tech University

Ahmed T (2012) Production optimization analysis of Kailashtila gas field. Dissertation, Shahjalal University of Science and Technology, Sylhet, Bangladesh

Ahmed MM, Ayoub MA (2014) A comprehensive study on the current pressure drop calculation in multiphase vertical wells; current trends and future prospective. J Appl Sci 14(23):3162-3171. https ://doi.org/10.3923/jas.2014.3162.3171

Ahmed F, Al-Amin AQ, Hasanuzzaman M, Saidur R (2013) Alternative energy resources in Bangladesh and future prospect. Renew Sustain Energy Rev 25:698-707. https://doi.org/10.1016/j. rser.2013.05.008

Aziz K, Govier GW (1972) Pressure drop in wells producing oil and gas. J Can Pet Technol. https://doi.org/10.2118/72-03-04

Bath E (1998) Introduction to well testing. Schlumberger

Beggs HD (1984) Gas production operations. Oil \& Gas Consultants International, Tulsa

Beggs HD (1991) Production optimization using NODAL ${ }^{\text {TM }}$ analysis. Oil, Gas Consultants International Inc, Tulsa

Beggs HD (2003) Production optimization: using NODAL analysis, 2nd edn. Oil. Gas Consultants International Inc., Tulsa

Beggs DH, Brill JP (1973) A study of two-phase flow in inclined pipes. J Pet Technol 25(05):607-617. https://doi. org/10.2118/4007-PA

BGFCL (2016) Annual report, Bangladesh Gas Fields Company Limited (BGFCL). A Company of Petrobangla, The Government of the People's Republic of Bangladesh (GOB), February

Bieker HP, Slupphaug O, Johansen TA (2006) Real time production optimization of offshore oil and gas production systems: a technology survey. In: SPE 99446 presented at the intelligent energy conference and exhibition, Amsterdam

Boyun G, Lyons WC, Ghalambor A (2007) Petroleum production engineering: a computer-assisted approach. Gulf Professional Publishing, Oxford

Brown KE, Lea JF (1985) Nodal systems analysis of oil and gas wells. J Pet Technol 37(10):1751-1763

CheGuide (2015) Double pipe heat exchanger design. Chemical Engineer's Guide, December 29. https://www.scribd.com/docum ent/381986629/Double-Pipe-Heat-Exchanger-Design-ChE-Guide

Christopher T, Uche O (2014) Evaluating productivity index in a gas well using regression analysis. Int J Eng Sci Res Technol 3(6):661-675

Coles D (1965) Transition in circular Couette flow. J Fluids Mech 21(3):385-425. https://doi.org/10.1017/S0022112065000241

Dake LP (1978) Fundamentals of reservoir engineering. Elsevier, Amsterdam

Dehua L, Guowei Z, Jing S, Wenying L (2011) Optimization design of horizontal wells development in low permeability gas reservoir in Su 53-4 well area. In: The second SREE conference on chemical engineering, Procedia Engineering, vol 18, pp 398-404

Economides MJ, Hill AD, Ehlig-Economides C, Zhu D (2013) Petroleum production systems, 2nd edn. Pearson Education, Prentice Hall, Englewood Cliffs 
Faruque MO, Hasan T, Hussain MA (2018) Optimization of gas-well production practices with special reference to Kailashtilla gas field, North-East, Bangladesh. J Sci Eng Res 9(7):1385-1396

Govier GW, Fogarasi M (1975) Pressure drop in wells producing gas and condensate. J Can Pet Technol. https://doi. org/10.2118/75-04-03

Gray HE (1978) Vertical flow correlation-gas wells. User Manual for API 14B, Subsurface Controlled Safety Valve Sizing Computer Program, App. B pp 38-41

Greene WR (1983) Analyzing the performance of gas wells. J Pet Technol. https://doi.org/10.2118/10743-PA

Guo B (2019) Well productivity handbook: vertical, fractured, horizontal, multilateral, multi-fractured, and radial-fractured wells, 2nd edn. Gulf Professional Publishing, Elsevier, Amsterdam

Gustafson Associates (2011) Updated Report on Bangladesh Gas Reserve Estimation 2010. Hydrocarbon Unit, Energy and Mineral Resources Division, Government of the People's Republic of Bangladesh, February 15, pp 141-152

Hagedorn AR, Brown KE (1965) Experimental study of pressure gradients occurring during continuous two-phase flow in smalldiameter vertical conduits. J Pet Technol 17:475-484. https://doi. org/10.2118/940-PA

Haq MB, Gomes E (2001) December. Estimation of gas in place of Bangladesh using flowing material balance method. In: 4th international conference on mechanical engineering, December 26-28, Dhaka, Bangladesh

Haq MB, Gomes E, Tamim M (2003) Production optimization yields new insights on Fenchugonj Gas field. In: International conference on mechanical engineering, December 26-28, Dhaka, Bangladesh

Haq MB, Gomes E, Tamim M (2005) Production optimization study of saldanadi gas field. J Chem Eng 23(1):47-52. https://doi. org/10.3329/jce.v23i0.5571

Hasanuzzaman M, Rahim NA, Saidur R, Kazi SN (2011) Energy savings and emissions reductions for rewinding and replacement of industrial motor. Energy 36(1):233-240. https://doi.org/10.1016/j. energy.2010.10.046

Hossain SM (2008) Production optimization and forecasting. Petroleum and Mineral Resource Engineering Department, BUET, April 29-30. https://www.scribd.com/doc/118212643/Production -Optimization

Hussain M (1987) Bangladesh energy resources and renewable energy prospects. Energy 12(5):369-374. https://doi.org/10.1016/03605442(87)90106-X

Ibelegbu C (2004) Productivity index in horizontal wells. J Sci Ind Res 63:979-984

Ibrahim ATM (2007) Optimization of gas lift system in Varg Field. Dissertation, Faculty of Science and Technology. University of Stavanger

Imam B (2013) Energy resources of Bangladesh: natural gas. Oil, coal, 2nd edn. University Grants Commission of Bangladesh, Dhaka

Islam MR, Muzemder ASH, Khan MAI, Hira MMA (2017) Rate transient analysis of Well-07 and Well-10 of Habiganj gas field, Bangladesh. J Pet Explor Prod Technol 7:569-588. https://doi. org/10.1007/s13202-016-0278-y

Jaf PTM (2015) Gas rate, GLR and depth sensitivities of gas lift technique: a case study. Int J Eng Technol Manag Appl Sci 3(7):138-149

Jansen JD, Currie PK (2004) Modelling and optimisation of oil and gas production systems. In: Lecture notes for course ta4490, production optimization, Version 5c, March, Section Petroleum Engineering, Delft University of Technology

Khor CS, Elkamel A, Shah N (2015) Optimization methods for petroleum fields development and production systems: a review. Optim Eng 18:907-941. https://doi.org/10.1007/s11081-017-9365-2

LGED (1999) GPS Field Survey. Local Government Engineering Department, GIS unit, Bangladesh
Maurer Engineering (1994) Multiphase flow production model (PROMOD1), Theory and User's Manual, Project to Develop and Evaluate Slim-Hole and Coiled-Tubing Technology (January 1994), DEA-67, Phase I, TR94-12. https://www.bsee.gov/sites/bsee.gov/ files/tap-technical-assessment-program//300ae.pdf

Midthun KT, Fodstad M, Hellemo L (2015) Optimization model to analyse optimal development of natural gas fields and infrastructure. Energy Proc 64:111-119. https://doi.org/10.1016/j.egypr o.2015.01.014

Mogensen AC (1991) Gas field production optimization. ACM Consulting Ltd. BUTE U of A Institutional Linkage Project, Report

Mohaghegh SD (2011) Reservoir simulation and modeling based on artificial intelligence and data mining (AI \& DM). J Nat Gas Sci Eng 3:697-705. https://doi.org/10.1016/j.jngse.2011.08.003

Nasir NF, Daud WRW, Kamarudin SK, Yaakob Z (2013) Process system engineering in biodiesel production: a review. Renew Sustain Energy Rev 22:631-639. https://doi.org/10.1016/j. rser.2013.01.036

Oddie G, Shi H, Durlofsky LJ, Aziz K, Pfeffer B, Holmes JA (2003) Experimental study of two and three phase flows in large diameter inclined pipes. Int J Multi Flow 29:527-558. https://doi. org/10.1016/S0301-9322(03)00015-6

Okoro ES, Ossia CV (2015) Production optimisation in the Niger Delta basin by continuous gas lift-a case study of Iduo-Well-A06. Int J Sci Eng Res 6(10):614-622

Ottba DJ, Al-Jawad MS (2006) Well preformance analysis based on flow calculations and IPR. J Eng 12(3):822-841

Petalas N, Aziz K (1998) A mechanistic model for multiphase flow in pipes. In: Conference paper in annual technical meeting, June 8-10, Calgary, Alberta. https://doi.org/10.2118/98-39

Petrobangla (2011) Annual report, Bangladesh Oil, Gas and Mineral Corporation (PETROBANGLA). www.petrobangla.org.bd. Accessed 25 Jan 2019

Rahman T, Akter F (2014) Production optimization of well HBJ\#06 of Habiganj Gas Field. In: International conference on chemical engineering, December 29-30, Dhaka

Rahman A, Seddique AA, Khan MHR, Rahman M (2017) Present gas reserve estimation using wireline logging data of Habiganj Gas Field, Bangladesh. Int J Oil Gas Coal Eng 5(4):44-50. https://doi. org/10.11648/j.ogce.20170504.12

Ravindran N, Horne RN (1993) Multivariate optimization of production systems: the time dimension (No. DOE/BC/14600-42; SUPRI-TR-90). Stanford University, Petroleum Research Institute, Stanford

Wan R (2011) Advanced well completion engineering, 3rd edn. Gulf Professional Publishing, Elsevier, Amsterdam

Roh J, Lim J, Park H, Kang MJ (2006) Gas production optimization of multi-reservoir fields using branch-system. Geosyt Eng 9(3):7380. https://doi.org/10.1080/12269328.2006.10541258

Ruysschaert RA (2012) Optimization of the lift gas compression system at the Eldfisk Complex. Dissertation, University of Stavanger, Norway

Saidur R, Rahim NA, Hasanuzzaman M (2010) A review on compressed-air energy use and energy savings. Renew Sustain Energy Rev 14(4):1135-1153. https://doi.org/10.1016/j.rser.2009.11.013

Salekin SM (2011) Optimization of a Saldanadi gas field of Bangladesh. Dissertation, University of Stavanger, Norway

Schlumberger (2000) Gas Lift Design and Technology. Chevron Main Pass 313 Optimization Project, December 09. https://studylib.net/ doc/14363057/schlumberger-gas-lift-design-and-technology

Shah MS, Hossain HMZ (2015) Evaluation of natural gas production optimization in Kailashtila gas field in Bangladesh using decline curve analysis method. Bangladesh J Sci Ind Res 50(1):29-38. https://doi.org/10.3329/bjsir.v50i1.23807 
Shah MS, Hossain HMZ, Kazal SS, TahsinS Rahman SW, Das J, Islam MS (2014) Assessment of unconventional gas recovery from Kailashtila gas field, Bangladesh. J Life Ear Sci 9:63-71

Shofiqul IM, Nusrat JL (2013) Reservoir characterization of Habiganj gas field. Int J Oil Gas Coal Eng 1(1):7-15. https://doi. org/10.11648/j.ogce.20130101.12

Sylvester O, Bibobra I, Augustina O (2015) Gas lift technique a tool to production optimization. Int J Oil Gas Coal Eng 3(3):41-46. https ://doi.org/10.11648/j.ogce.20150303.12

Tan XH, Liu JY, Zhao JH, Li XP, Zhang GD, Tang C, Li L (2014) Determine the inflow performance relationship of water producing gas well using multi-objective optimization method. J Appl Math. https://doi.org/10.1155/2014/105636

Vieira C (2015) Model-based optimisation of production systems case study: gas-lift method. Dissertation, Department of Petroleum
Engineering and Applied Geophysics, Norwegian University of Science and Technology

Wang P (2003) Development and applications of production optimization techniques for petroleum fields. Doctoral Dissertation, Stanford University

Wang P, Litvak ML, Aziz K (2002) Optimization of production from mature fields. In: 17th World Petroleum Congress, September 1-5, Rio de Janeiro, Brazil

Publisher's Note Springer Nature remains neutral with regard to jurisdictional claims in published maps and institutional affiliations. 